\title{
Research on the Countermeasures of Constructing the Guarantee Mechanism of Government Funds Investing into the Home Care Service
}

\author{
Wenxiong $\mathrm{Yu}$ \\ School of literature, law and economics \\ Wuhan University of Science and Technology \\ Wuhan, China
}

\author{
Lilin Liu \\ Central Southern China Electric Power Design Institute \\ Wuhan, China
}

\begin{abstract}
Government funds shoulder the responsibility of construction of home care service agencies, the purchase of home care service, and guiding social funds into home care service industry. Both home care service cause and home care service industry are indispensable from the overall planning of government funds and achievement of long-term mechanism. First of all, for the home care services, the form, scale and method of government financial support should be institutionalized, and the stability and effectiveness of government funding should be ensured through the construction of a guarantee mechanism for government funds. Secondly, when government funds guide social funds to promote the home care service industry in the market-oriented way, it is necessary for the government to make clear the industrial plan for home care services and improve the government's tax incentives.
\end{abstract}

Keywords-government funds; home care service; guarantee mechanism

\section{INTRODUCTION}

In the process of building home care services, the government's capital investment plays a decisive role. The way and intensity of support of government's fund for home care service is the sign for development of the entire elderly care service market, which strongly promotes the development of the elderly care service industry. It can be said that the initial motive force for the development of the elderly care service industry depends on government funds. Its lasting power depends on the market, namely the social funds.

\section{INCLUDING THE GOVERNMENT BUDGET TO FORM SPECIAL FUNDS}

To form a long-term mechanism for government funds to invest in home care services and achieve the stability of capital investment, the most important thing is to unify the sources and raise the level of capital expenditures to the government budget so as to effectively avoid the risk of under-funded home care services.

Although most of the funds for home care services in China rely on government expenditures, the sources are extremely complicated and involve cities, districts, towns (counties) and street governments. For example, the training fees of attendants come from the skills training funds of employee outside the city, and their salaries are from employment promotion specific funds of the city, district and county levels. Different home care service projects have different sources of funding. The direct result of such management approach is that the implement of home care services requires coordinated management of multiple sector, which may form multi-head management. Excessive sources of funds can easily lead to excessive funding using costs. Since it is not easy for a number of funds to arrive at the same time, inconsistent steps of the use of funds will lead to inefficient use of funds.

Therefore, including the home care service funds into the government's financial budget can clarify the government's responsibility of capital expenditure in home care services and it is also an important action reflecting the government's concern for the livelihood and social welfare.

\section{OPTIMIZING THE INPUT STRUCTURE OF GOVERNMENT FUNDS}

When the government invests money in home care services, it takes the form of tertiary level section including municipal, district (county) and streets section. For different home care services such as cities, districts (counties) and streets, the structure of government funding should be adjusted with the social development.

The input structure of government funds in home care services is mainly the comparison of the scale of the home care services agencies and home care services. As more social funds are involved in the provision of home care services, government funds should play the guiding role in gradually reducing their investment in home care services and leading more market organizations to participate in the provision of home care services.

\section{A. Making Full Use of the Leading Role of Government Funds}

Under the background of the socialization of social welfare, government funds should adjust and change 
correspondingly in the expenditure of the construction and operation cost of home care services. Over $50 \%$ of the government funding for home care services agencies has been used for the training of staff and operating cost of remuneration of home care services, while the construction cost for home care services agencies is less than the operating expenses. Unreasonable proportion of capital investment makes the government mainly undertake the responsibility of income of home care services workers while it shoulder a little in the provision of facility and professional services equipment of home care services, or that the larger operating costs occupy the space of construction costs. The main responsibility of the government is to apply more funds to the construction of home care services.

\section{B. Encouraging Social Forces to Participate in the Provision of Home Care Services}

From the current practice in China, the government shoulders the dual responsibilities of provision of home care services and purchase home care services, with less market power participation. This may be related to the public welfare of home care services and the government can adopt more flexible measures to encourage social forces to provide endowment services, including both non-profit organizations and private market organization. For example, we can adopt the method of subsidizing rewards instead of subsidies, and change the way of subsidizing home care services providers in the past. By introducing market mechanisms, we can reward the better institutions with capital according to competitive results. With more social forces participating in the provision of home care services, more social forces can participate in the provision of home care services, so that the government funds can be invested in a targeted manner.

\section{The Fairness of the Purchase Can Be Reflected More in the Content of Government Purchase}

The government subsidizes the elderly in the form of home care services, so the aged benefit the largest. Therefore, the contents of subsidies of government purchase should reflect the fairness of the old-age welfare system and pay more attention to the elderly who lost the only child and empty nester. First of all, the fairness of the old-age welfare system should be reflected. Due to the implementation of the household registration system in China, when introducing the qualifications of subsidized service objects, it should be clearly defined the city's elderly residents. In consideration of the fairness of elderly welfare system in China, we should give full consideration to the retirement needs of nonhousehold seniors when providing home care services subsidies for the elderly through the form of government procurement. We can also subsidize the elderly in line with the requirement in part or in full subsidies by comprehensively assessing the overall situation of income of the elderly and their children. The government should expand the scale of government purchases based on the fairness of the population covered by home care services because compared with the elderly with residence, the possibility for the elderly without residence to fall into poverty is bigger. Due to the inability to enjoy the hidden benefits of the household registration system, the pension needs of these elderly people are often overlooked. Therefore, expanding the scale of government procurement and reducing the difference between household registration and non-household registration can effectively reduce the poverty of the elderly and conduce to providing assistance to vulnerable groups.

Second, more attention should be paid to the elderly who have lost their only child and empty nesters. In China, the elderly who lost the single child are the special groups that emerged under the policy of implementing family planning in China. When the issue of shidu family is gradually emerging, there is an increasingly serious trend. The government should increase the purchase of old-age service of empty nesters and the elderly without the only child and promote social fairness and harmony.

\section{FORMING A STABLE PROPORTION OF CAPITAL INVESTMENT}

The important aspect of forming a long-term investment mechanism for government funds in providing home care services and safeguarding the stability of capital investment is the formation of a stable proportion of government funding. Only when different levels of government invest funds in a relatively fixed way with relatively stable and reasonable proportion of investment composition, the implementation of home care services can form scale. The stability and durability of work plays a strong role in promoting the formation of home care services market in the initial period, which will gradually guide the home care services industry to develop towards the direction of normalization.

Determining the investment proportion of government at all levels in home care service, on the one hand can enhance the stability of fund guarantee of home care services, and on the other hand can contribute to clarifying the economic responsibility of government at different levels in different home care services, and highlight the matching of financial rights and powers of government at all levels. Taking Australia and Japan as an example, the ratio of investment from central and local governments of home care and community care in Australia account for 6: 4. The government bears half of the premium of long-term social care insurance in Japan, of which the central government pay $50 \%$ and municipal and county governments bear $25 \%$ respectively.

\section{ESTABLISHING A STANDARDIZED FUNDS TRANSFER PAYMENT SYSTEM}

The funds for home care services involve funds of three levels government agencies in city, district (county) and street and different types of project funds. The unbalanced economic development in different regions is also obvious. Although the distribution of funds can reach unity at the municipal level, however, at district (county) level, their different ability to raise funds will also affect the implementation of home care services. Therefore, considering the unbalanced economic development in 
different regions, the establishment of a standardized fund transfer payment system can solve the problem of insufficient funds in some areas and achieve equalization of public home care services.

Establishment of standardized fund transfer payment system can be based on the government's budget. If the financial budget expenditures of district / county-level governments related to home care services exceed their financial revenues, municipal-level government can make funds transfer payment to the district (county) level government. At the same time, the government at higher level should also do a good job in auditing and supervising to ensure the reasonable fund transfer payment. At the same time, when formulating the fund transfer payment system, it is also necessary to clarify the efficiency of fund transfer payments. On the other hand, corresponding measures should also be taken through fund transfer payment methods so as to enhance the using efficiency of government funds at the lower level and prevent the funds of government at lower level from overly depending on the funds of government at the higher level. Similarly, we can also consider the mutual fund transfer payments between governments at the same level, and the corresponding constraints can truly exert the effect of fund transfer payment system to support the grassroots governments in carrying out home care services in the community.

\section{INCREASING THE FINANCIAL SUPPORT OF WELFARE LOTTERY, CHARITY AND SOCIAL CONTRIBUTIONS TO HOME CARE SERVICES}

Since China issued welfare lottery, it clearly stipulates that the purpose of the public welfare fund of welfare lottery is to help the elderly and the disabled, save the orphan and help the poor. It is operated through a special issuance agency under the government and the welfare funds raised are not included in the national income. Instead, they are directly used to develop social welfare and social assistance projects as an important channel for replenishing funds. At present, the public welfare fund of welfare lottery, philanthropy and social donations all contribute tremendously to the financial support of home care services in China. Likewise, the development of old-age care cannot be separated from the social welfare undertakings and the vigorous support of philanthropy.

\section{A. Further Expanding the Investment of Public Welfare Fund of Welfare Lottery in Home Care Services}

Using public welfare fund of welfare lottery for home care services fully explains the feature of commonweal of home care services. The purpose of public welfare fund of welfare lottery is mainly providing the construction of the existing home care services at the end of home care services for the poor elderly, such as the start-up costs of meal-aid station and elderly-helping service agencies and the purchase subsidies of home care services. Although public welfare fund of welfare lottery plays a major role in old-age service work in China, the payment of its funds is still relatively small compared with the total government revenue. From the perspective of the development of home care services in the future, home care services still need the investment of public welfare fund of welfare lottery to ensure their public welfare funds, but the supportive power of the funds is still mainly based on the government's financial strength. However, this does not mean that public welfare fund of welfare lottery do not need to expand investment.

\section{B. Increasing the Financial Support of Philanthropy for Home Care Services}

The commonweal of home care services can attract more charities, public welfare funds and social donations to provide financial support for them. The government should introduce relevant policies, training and other methods to promote the financial support of charity and social donations for home care services.

There are many special social volunteers or voluntary workers at home and abroad. The elderly who live in elder care center need much spiritual comfort and volunteers can listen to the voices of the elderly, be happy and good at communicating with the elderly, which provides financial support for home care services from another perspective. The government should provide these volunteers with some psychological training to enable them to better understand the psychological characteristics and behaviors of the elderly so as to provide spiritual care services for the elderly with a more careful and meticulous attitude and at professional level.

\section{Continuing to Implement the Taxation Reducing Policy on Agencies Providing Social Donation for Home Care Service}

The new "corporate income tax" law, introduced in 2008 stipulates that the portion of expenditures for charitable donations made by enterprises that is within the $12 \%$ of annual profit should be deducted The portion of the public welfare donations and relief donations made by individuals that is less than $30 \%$ of the taxable income in the year should be deducted. Through comparative analysis, the government should give encouragement to the financial support of philanthropy and social donations for home care services, and should further increase the proportion of pre-tax deductions for social donations and retain the preferential policies for full deduction, both for enterprises and individuals making social donation.

From the development track of the old-age service industry in foreign countries, the leading role of the government is vital in the early stage of the development of old-age service industry. When supporting the development of the industry, the government has adopted such policies and measures as guidance for the old-age service industry, vocational training for human resources and tax incentives for old-age service enterprises.

With the gradual socialization of old-age care functions, social forces have become the main providers of home care services. Although the nonprofit organizations currently providing home care services depend on the government funds, from the perspective of long-term operation of home care services, it is the foundation of sustainable operation of 
home care services funds to develop the home care services industry centering on the market mechanism. In the developing process of marketization, the planning and guidance of government for home care services is indispensable. When maintaining a market environment with fair competition, the government should take the measure of tax preference to encourage private capital to enter the home care services industry, not only for enterprises and social organizations providing old-age care services but also for enterprises and individuals providing financial contributions for home care services.

\section{FOSTERING MARKET ENVIRONMENT WITH FAIR COMPETITION}

Marketization development of home care service industry is to form a free and fair competition market environment, reduce government administrative intervention, and achieve a healthy, orderly and sustainable development of the home care service industry. From the perspective of home care services practice in China, home care services cause is still fully supported by the government. Although there is also involvement of civil and private capital, the government still holds the dominant position in market forces. Due to the commonweal nature of the home care services industry, most of the organizations participating in home care services are non-governmental private organizations, namely non-profit organizations. Judging from the development of non-profit organizations at this stage in China, most non-profit organizations engaged in home care services have government background and depends on the government in funds. Therefore, marketization development of the home care services needs to reduce the influence of the government intervention. The most important thing is to handle the financial relationship between the government and non-profit organizations.

\section{A. Forming a Good Financial Relationship between Government and Non-profit Organizations}

The source of revenue of international non-profit organizations are mainly from membership dues, service fees, operating income, social donations (including personal donations and corporate donations), and government subsidies. The United States is a typical representative of market-based financing model of the non-profit organization. The United States government basically does not directly engage in social welfare undertakings, but entrust nonprofit organizations to provide public services by way of project bidding. Non-profit organizations bid according to their own professional characteristics and advantages to apply for project funds of public welfare. The government will review and inspect the non-profit organizations submitting application and grant project funds for non-profit organizations that meet the requirements. The government does not intervene in the usage of funds, but it regulates the operation of the project.

Therefore, referring the interaction of funds between the government and non-profit organizations in developed countries, the relationship between Chinese government and nonprofit organizations providing community old-age care should change the current situation of non-profit organizations relying on government subsidies, and reduce the administrative intervention of government to organizations. The government can purchase services from non-profit organizations through open bidding and in the way of outsourcing contracts, so that non-profit organizations bidding in a competitive market environment can not only fully guarantee the quality of services they provide, but also guarantee the effectiveness of funds provided by government for non-profit organizations. At the same time, the government should also supervise the use of funds of the profit organizations. The project should take the form of open competition before the project is purchased. After the project is purchased, a corresponding evaluation mechanism should be put in place to supervise the use efficiency of the funds.

\section{B. Giving Full Play to the Role of Market Mechanism}

Giving full play to the role of market mechanism is to reflect the role of prices in the home service markets. Although the old-age care service industry has its own characteristics of commonweal, not all home care services companies must engage in public service activities. If we want to industrialize home care service industry, we must make the old-age care service enterprises be profitable, and have profit to share. In other words, even nonprofit organizations providing old-age care services can also provide public home care services and non-public home care services. Public and non-public old-age care services aims at the needs of the elderly with different income. For the oldaged service needs of poor elderly, the government has the obligation to assume the financial responsibility to provide public goods, and the old-age services with public product attributes should be not profitable or with meager profit, but such service products guarantee the basic needs of the elderly. For elders with better economic conditions, their oldage care services are no longer public products and can be purchased from the market, so they can choose personalized old-age services in accordance with their own needs. Such old-age service products have much higher standards in service content and quality, so it should be completely nonpublic, or for profit.

\section{DEVELOPING OLD-AGE REAL ESTATE ACCORDING TO THE MAINTENANCE PRACTICES}

For the western countries, everyone advocates independence and freedom. When an adult marries, children choose to leave their parents and live independently. Similarly, older people will choose to live independently even after they are old and retire. Under such a cultural background, the issue of care service for the elderly mainly depends on the society and the country has a perfect social security system to realize the socialization old-age care of the elderly. The elderly generally have abundant pensions after old age. According to their health condition and willingness, they can choose to live in different types of senior apartments and nursing homes. The communities where these senior residences are located can provide sound social services that basically meet the needs of the care needs 
of the elderly. In the Asian countries in the East, due to the influence of Confucian culture, the traditional consciousness still takes family as the core. Demand for house has always been a rigid in our country. Almost every household, especially urban residents, buys houses to stabilize their life. It seems that house has become a symbol of family life and psychological belongingness. Judging from the actual situation of houses purchase of families at present, families spend a considerable portion of the income of both parents and children on housing. Therefore, it is a good idea to develop old-age real estate in combination with old-age care function of the housing and family. Therefore, combining the development momentum of the old-age real estate and the maintenance practices of China, we can learn from the practices of Asian countries like Japan and Singapore. Because China has similar traditional culture with these countries, which is different from western countries in the issue of elderly care, we can try to develop the old-andyoung-living-together old-age care real estate in the residential arrangement and way of old-age care. The function of old-age real estate should emphasize the function of old-age care and the design and construction of houses should pay attention to the adaptability of the elderly. Moreover, the developed communities have corresponding facilities for the elders and medical and health facilities that can provide services that meet the different needs of the elderly. In addition, for public beneficial ensuring house, the government can consider making some old-adapting designs in housing construction. For children who are willing to live with the elderly, they will be given some preferential policies or rent discounts when applying for ensuring house.

\section{CONCLUSION}

Government funds play an important leading role in the comprehensive promotion of home care services. The ways, methods and focuses of fund investment are related to the development of old-age care cause and old-age care industries. How to build a long-term mechanism for government funds investment is the key problem of this article. On the one hand, we should build a guarantee mechanism for government funds. That is to say, the government include the funds for home care services into the budget to form special funds to optimize the investment structure of funds of the government for the construction and purchase of home care services, form a stable capital investment ratio, establish a standardized fund transfer payment system, and increase the support of welfare lottery and public welfare services for home care services; on the other hand, we should actively play the guiding role of government funding policies, foster public competition market environment through a clear plan for home care services industry, improve the tax preference of government and develop old-aged real estate to promote the development of home care service industry.

\section{REFERENCES}

[1] T. Fukawa. Household Projection and Its Application to Health/Long-term Care Expenditures in Japan using INAHSIMII[J].Social Science Computer Review.2011,1.52-56.
[2] Terence Ng. Charlene Harrington and Martin Kitchener. Medicare And Medicaid In Long-Term Care[J].Health Affairs.2010.29(1).2228.

[3] Thomas Davidoff. Home Equity Commitment and Long-term Care Insurance Demand[J].Journal of Public Economics.2010(94).44-49.

[4] W.S. Chan,S. H.Li and P.W. Fong. An Actuarial Analysis of Longterm Care Demand in Hong Kong[J].Geriatrics\&Gerontology International.2004.S143-S145.

[5] Cao Meijuan, Chen Lingyu. "survey on the demand for home care services of the urban elderly living alone", Chinese Nursing Research, 2012, No.6.

[6] Zeng Yi, Chen Huaishuai, Wang Zhenglian. "analysis on the changing trend of demand cost of the elderly home care service in the first half of the 21st century", "Economic Research journal", 2012, No. 10.

[7] Zha Jianhua: "A Comparative Study of the Development of Aging Industry between China and Japan", Journal of Shanhai Finance University, 2011, No.4

[8] Lv Liangsi: "how the old-age care institutions establish social workerled assessment mechanism", "China Civil Affairs", 2010, No.8.

[9] Mu Guangzong, Yao Yuan: "Exploring the Future road of Comprehensively solving the Aging problem with Chinese Characteristics", Population \& Economics, 1999, No. 2. 